\title{
2 The Emergence of the Middle East into the Modern State System
}

\author{
EUGENE L. ROGAN
}

Introduction: the Arab entry to international relations

Ottoman diplomacy

An Ottoman legacy of statehood

Wartime plans for the partition of the Middle East

The post-war settlement, 1919-22

The colonial framework

The Arab states and the Palestine crisis

Conclusion

Key events 58

Further reading

\section{Overview}

The modern states of the Arab Middle East emerged from the collapse of the Ottoman Empire and the post-First World War settlement. The fall of the Ottoman Empire left the Turks and Arabs ready for statehood, although unprepared for dealing with the international system. The experience of Ottoman reforms had left an important legacy of statecraft in the Arab world. While the Arab people were thus prepared for statehood in 1919, they had little prior experience of diplomacy. In Ottoman times, relations with the European powers had been mediated through Istanbul. Moreover, the Arab lands constituted provinces of a common state, rather than distinct states with their own national boundaries, and thus had no experience of dealing with other Arab communities as foreign states. The Arabs had no say in the post-war partition of their lands under League of Nations auspices, 
$\mathrm{CH}-02$ The Emergence of the Middle East into the Modern State System distributed among the victorious powers as a new form of colonial state known as 'mandates'. Nationalist movements emerged within the confines of these new states in opposition to colonial rule. This legacy would leave the Arab world struggling between a widely held ideal of Arab unity and a reality of nation-state nationalism reinforced by nationalist struggles for independence. The Arab states post-independence were divided by factionalism and infighting. These divisions were apparent in the first issue to test the independent Arab state system: the Palestine crisis (1947-49). The new states of the Middle East have proven remarkably stable, although in their genesis lay the foundations for many of the conflicts that have subsequently troubled the region.

\section{Introduction: the Arab entry to international relations}

The Arab world made its entry into international relations at the Versailles Peace Conference following the First World War. Prior to the war, the Arab lands of North Africa had been colonized by France, Italy, and Britain, while the majority of the Asian Arab lands had been under Ottoman rule. The Arab delegations, newly independent of the defeated Ottoman Empire, came to Versailles to seek those essential attributes of independent statehood: juridical equality with other states, and absolute sovereignty (Bull and Watson 1984: 23). They faced two major impediments. To start, there was no consensus among the Arabs on the post-war state structure that was to be sought. While some delegations came to present demands for discrete national states like Egypt or Lebanon, others pursued a broader vision of Arab statehood. The Arab delegations were thus working at cross-purposes. The Europeans posed the second impediment to Arab ambitions. As Hedley Bull asserted, 'non-European states entered an originally European club of states as and when they measured up to the criteria of admission laid down by the founder members' (Bull and Watson 1984: 123). The Arabs faced real disparities of structural power in negotiating with the Europeans, who harboured imperial interests in the Eastern Mediterranean and whose soldiers still occupied Egypt, Palestine, Syria, and Iraq.

The dilemma that the Arab delegations to Versailles faced was common to all newcomers to the international order: admission to international society was conditional on recognition of sovereignty and 'states do not have sovereignty apart from recognition of it by others' (Bull 1984: 122). The entry of many Asian and African states to international society would face the same constraints (Bull and Watson 1984; Clapham 1996). 
$\mathrm{CH}-02$ The Emergence of the Middle East into the Modern State System The very institutions governing the workings of international society in 1919 were little changed from the previous century. The governance of the system was in the hands of the great powers, which played a decisive role in codifying the norms of the system in a set of regulatory rules of war and peace known as 'international law'. The powers met and applied international law to resolve conflicts through congresses such as Versailles. Outside periods of conflict, relations between states were maintained through diplomatic missions (Watson 1984: 24-5, 27).

Almost without exception, the new states of Asia, Africa, and the Middle East were alien to the institutions of the European system of international relations. Those North African states already under European colonial rule before the outbreak of the First World War had surrendered control of their foreign relations to their colonial masters. Those Arab territories that had formerly been part of the Ottoman Empire had never known formal relations with outside powers, because the Empire's foreign relations had been conducted through the imperial capital, Istanbul. Indeed, the Ottomans themselves were relatively recent entrants to the European system of diplomacy.

\section{Ottoman diplomacy}

The Ottoman Empire was a 19th-century newcomer to the European state system. Up to the reign of Sultan Selim III (1789-1807), Ottoman relations with Europe were based on a unilateral system whereby European ambassadors were received by the Porte (the central government), but no Ottoman permanent missions were sent to European capitals. Ottoman ambassadors were dispatched infrequently, for specific missions, and returned to Istanbul, often with extraordinary stories of the alien culture that they had encountered (Itzkowitz and Mote 1970; Göcek 1987). European states conducted their relations with the Ottomans through trade companies such as the English Levant Company (established 1581). European merchants resident in Ottoman domains enjoyed extraterritorial rights to be judged by their own nation's laws, as set out in a series of bilateral treaties known as the 'Capitulations'. The first Treaty of Capitulation was drafted in 1352 with Genoa, followed by similar treaties with Venice and Florence. In 1535, a commercial treaty was negotiated between France and the Porte, and a formal negotiated Capitulation concluded in 1569, followed by similar instruments 
$\mathrm{CH}-02$ The Emergence of the Middle East into the Modern State System with England (1580) (Hurewitz 1975: 1-10). The Capitulations were drafted when the Ottomans were the dominant Mediterranean power and saw little need for more formal relations with Christian Europe. Selim III’s first experiment of reciprocal diplomacy, establishing embassies in London, Vienna, Berlin, and Paris in the 1790s, was most remarkable for its bad timing: the French Revolution and the Napoleonic Wars were low points in the European state system.

It was only when Europe began to intervene in Ottoman affairs to prevent the fall of the Sultan's government that the Ottomans were assimilated into the European state system. The two Egyptian crises (1831-32 and 1839-40) led the European powers to enter Ottoman domains to contain the ambitions of Egyptian governor Mehmet Ali Pasha_and each other. The London Convention of 1840, resolving the Second Egyptian Crisis, marked the Ottoman entry to continental European politics. It was the first European convention signed by Ottoman diplomats on behalf of the Sultan. What is more, British Prime Minister Lord Palmerston drafted a secret ‘self-denying protocol’ adopted by Britain, Austria, Prussia, and Russia, pledging that no power would seek territorial or commercial gains in Ottoman domains to the exclusion of any other power (Hurewitz 1975: 271-5).

The Ottomans formally joined the Concert of Europe in 1856 when they signed the Treaty of Paris marking the end of the Crimean War, along with Britain, France, Austria, Prussia, Russia, and Sardinia. The Ottomans were entering a system whose rules they had no say in drafting and of whose terms they had at best an incomplete knowledge. The Ottoman foreign ministry had been established only in 1836. In the course of the 19th century, permanent embassies were opened in European capitals and Istanbul received ambassadors from the great powers, which residences still grace the European quarters of Istanbul. Diplomacy in Ottoman domains was thus almost exclusively confined to the imperial capital. While European consuls were posted to key provincial cities such as Jerusalem, Beirut, Damascus, and Aleppo, their interaction was with Ottoman governors, mediated through Istanbul. Local Arab Muslims had little or no contact with these foreign dignitaries and no experience of the international system. 
$\mathrm{CH}-02$ The Emergence of the Middle East into the Modern State System

By 1878, Palmerston’s 1840 ‘self-denying protocol’ had lapsed. The Ottoman Empire had declared bankruptcy to its European creditors (1875). Battles with Bulgarian nationalists seeking independence from Ottoman rule had been reported in the European press in terms of atrocity and led to a disastrous war with Russia in 1877-78. Utterly defeated, the Ottomans were forced to accept enormous territorial losses: Britain claimed Cyprus as a colony; Britain and Germany gave France the nod to occupy Tunisia; and, in the Treaty of Berlin, the Ottomans were forced to cede some two-fifths of their territory, mostly in the Balkans. In 1882, Britain occupied Egypt, still officially Ottoman territory. The European powers had embarked on the dismemberment of the Ottoman Empire that would reach its climax in the secret agreements concluded in the course of the First World War.

Yet, in the last quarter of the 19th century, the collapse of the Ottoman Empire was far from inevitable. Despite Ottoman territorial losses to European states and Balkan nationalist movements, reforms proceeded apace in the institutions of statecraft. The influence of these reforms would prove an enduring legacy in Arab lands.

\section{An Ottoman legacy of statehood}

It was the common wisdom of the peacemakers at Versailles that the Arabs had no experience of statecraft when, following the collapse of the Ottoman military in the First World War, they first emerged among the community of nations. The exceptions were those North African countries that had developed instruments of statehood, all of which were under direct colonial rule in 1919: Morocco, the oldest formal Arab state, became a French protectorate in 1912; Tunisia had been under French rule and Egypt under British rule since the 1880s. Algeria, the first Arab territory to come under European colonial rule (1830), was assimilated to metropolitan France and never had the chance to develop autonomous instruments of rule to the same extent as the other North African states.

When speaking of 'the Arabs', the victors at Versailles were referring to the Arab provinces of the Ottoman Empire. The Arab lands formally under Ottoman rule in 1914 were Yemen, the Red Sea province of the Hijaz, 
$\mathrm{CH}-02$ The Emergence of the Middle East into the Modern State System Greater Syria (comprising the modern states of Syria, Lebanon, Jordan, and Israel/Palestine), and Iraq. Tenuous Ottoman claims to the Najd region of central Arabia, and the Persian Gulf sheikhdoms stretching to Qatar, had lapsed by 1913 (Anscombe 1997). Britain and France, intent on adding these territories to their colonial possessions as spoils of war, claimed that the newly liberated Arab lands were not ready for independence, but would first require a period of tutelage in statecraft.

While none of these lands comprised a state in its own right, each had enjoyed extensive exposure to Ottoman instruments of state, particularly since the period of reforms in the second half of the 19th century. The Ottoman reforms, known as the 'Tanzimat' (1839-76), were in small part designed to preclude European pretexts to intervene in Ottoman affairs. Arguably, the chief aim of the reforms was to make for a more viable Ottoman state and to consolidate Istanbul's hold over its Asian provinces as nationalist movements led to the progressive secession of the Balkan provinces.

Much of the literature on the Tanzimat has focused on issues of minority rights, and the equality the reforms established between Muslims and non-Muslims. This was a measure taken by the Ottomans to prevent the European powers from exploiting minority issues to intervene in Ottoman domestic affairs. However, as a reform process the Tanzimat was far more significant in the realm of domestic governance and financial regularity. Seen in this light, the milestones of the Tanzimat were not the major policy pronouncements made by the Sultan (the Reform Decrees of 1839 and 1856, and the Constitution of 1876) so much as the 1858 Land Law, the 1864 Provincial Governance Law, and the promulgation of the civil law code known as the 'Mecelle' (1870-76). These were the measures that introduced rational bureaucracy, fiscal regularity, a consistent rule of law, and growing contact between Ottoman subjects and their government. What is more, the era of reforms did not end in 1876, but continued across the reign of Sultan Abdülhamid II (1876-1909), dubbed by one author as 'the culmination of the Tanzimat'. As Stanford Shaw argued, 'Every aspect of the Ottoman system was included [in Abdülhamid II's reform agenda] — the military, the central administration, the provinces, the law courts, finance, the economy, public works, education, fine arts, and the administration' (Shaw and Shaw 1978: 221). The reforms in this sense extended from 1839 through the first decade of the 20th century. 
$\mathrm{CH}-02$ The Emergence of the Middle East into the Modern State System

Arguably, the Arab provinces of the Ottoman Empire were initiated in statecraft in the last quarter of the 19th and the first two decades of the 20th centuries. This education involved direct knowledge of and contact with the government bureaucracy, and a subordination to the 'rule of books' through the census, land registration, the tax office, and military conscription. Arab Ottomans came to know the complexity of government, at both the provincial and the imperial levels. The Arabs also had their first experiences of elected office at this time, both at the provincial level, to town and regional councils, and to the Imperial Parliament, in 1876 and again after 1908. A consistent rule of law was applied and enforced by police and gendarmes in the countryside and by courts in the towns.

What is more, residents of the Arab provinces came to associate certain benefits with the exercise of statecraft. The extension of the rule of law brought a new degree of security, particularly in the countryside. The rapid expansion of the primary and secondary school system in the provinces broadened literacy and witnessed a growing number of locals entering the civil service-in the Arab provinces as well as in Turkish Anatolia (Findley 1989; Somel 2001). A clear sense of ‘citizenship’, with attendant rights and responsibilities, appears in correspondence written by Ottoman subjects to Ottoman officialdom. Arabs in the provinces found a political voice assertive of individual rights, property rights, constitutional law, justice, and humanitarianism in their telegraph communications with Ottoman officialdom (Rogan 1998: 123-6).

It is striking how the victorious European powers shaped the Arab state system in the image of Ottoman provincial government. After the 1864 Provincial Reform Law, Ottoman provincial capitals were the focus of extensive investment and construction. Government buildings (administrative offices, courthouses, barracks), communications infrastructure (post, telegraph, roads, trams, and railways), and commercial and residential quarters underwent rapid development in the latter 19th century. Provincial capitals such as Jerusalem, Beirut, Damascus, and Baghdad were easily adapted to make national capitals in the mandates of Palestine, Lebanon, Syria, and Iraq.

Taken together, these aspects of late Ottoman rule constitute a legacy of 'stateness' that had prepared the Arab people for some degree of self-rule by 1919 (Rogan 1999). To some extent, this was acknowledged in the Covenant of the League of Nations: 
$\mathrm{CH}-02$ The Emergence of the Middle East into the Modern State System Certain communities formerly belonging to the Turkish Empire have reached a stage of development where their existence as independent nations can be provisionally recognized subject to the rendering of administrative advice and assistance by a Mandatory until such time as they are able to stand alone. The wishes of these communities must be a principal consideration in the selection of the Mandatory.

(Article 22)

Given their more advanced state of development than the other mandated territories, in Central and SouthWestern Africa, as well as in the Pacific Islands, the Arab lands were designated 'type A' mandates—-that is, proto-states in need of interim tutelage in preparation for independent statehood. However, this was not to be. For the whole of the inter-war years, all Arab states bar Iraq remained under de facto British or French colonial rule. The origins of this colonial division date back to the time of the First World War.

\section{Wartime plans for the partition of the Middle East}

In the course of the First World War, Russia initiated the wartime diplomacy for the partition of Ottoman territory. In March 1915, as Allied warships assembled outside the Dardanelles, the Tsarist government staked claims to the Ottoman capital Istanbul and the strategic waterways linking the Black Sea to the Mediterranean - the straits of the Bosporus, the Sea of Marmara, and the straits of the Dardanelles. France responded by declaring its interest in securing Syria and the Cilician coastline for its empire. Britain at that stage had no clear territorial interests in Ottoman domains but went along with its allies' demands, reserving the right to make its own territorial claims at a later date. The Constantinople Agreement, concluded between Russia, France and Britain in March 1915, was the first of four wartime agreements that would determine the shape of the modern Middle East (Hurewitz 1979: 16-21).

Britain struck the second wartime agreement to conclude an alliance with the Arab movement against the Ottomans. Between July 1915 and March 1916, British High Commissioner for Egypt Sir Henry McMahon and the Sharif of Mecca, Hussein ibn Ali of the Hashemite family, negotiated the terms for an Arab revolt against Ottoman rule. In exchange for opening this internal front against the Ottomans, Sharif Hussein sought British support for an enormous Arab kingdom stretching from Mersin and Adana (in modern Turkey) to 
$\mathrm{CH}-02$ The Emergence of the Middle East into the Modern State System Persia in the north, to the Persian Gulf, the Indian Ocean, the Red Sea, and the Mediterranean, excluding the British colony of Aden. McMahon responded, in his famous letter of 24 October 1915, with British acceptance of these boundaries, with the sole exclusion of the 'two districts of Mersina and Alexandretta and portions of Syria lying to the west of the districts of Damascus, Homs, Hama and Aleppo' and those areas in Mesopotamia of strategic interest to Great Britain (Hurewitz 1979: 50). With these assurances, Sharif Hussein initiated in July 1916 the Arab Revolt made famous by T. E. Lawrence.

While Britain's representatives in Cairo were negotiating with Sharif Hussein, the British Foreign Office initiated negotiations with the French Ministry of Foreign Affairs to reconcile the pledges to the French made under the Constantinople Agreement with McMahon's promises to the Arabs. This third agreement, known by the names of its British and French authors, Sir Mark Sykes and Charles François Georges-Picot, was approved on 4 February 1916 and gained Russian support in March 1916 in exchange for Anglo-French agreement to Russian territorial demands in Eastern Anatolia. According to this agreement, France would establish an administration in those areas that Sir Henry McMahon had excluded from the Arab kingdom—-the 'two districts of Mersina and Alexandretta and portions of Syria lying to the west of the districts of Damascus, Homs, Hama and Aleppo'—while Britain would establish an administration in Mesopotamia. The inland territories between these areas were to be divided into British and French spheres of influence, with Palestine internationalized to prevent disagreement between British, French, and Russian claims to the Holy Lands (Hurewitz 1979: 60-4).

Finally, on 2 November 1917, the British government gave formal support to the aspirations of the World Zionist Organization to establish a Jewish national home in Palestine. The Balfour Declaration, transmitted in a letter from Foreign Minister Arthur James Balfour to Lord Rothschild, confirmed Britain’s support for ‘the establishment in Palestine of a national home for the Jewish people' (Hurewitz 1979: 106). The Balfour Declaration contradicted both the pledge to Sharif Hussein and the Sykes-Picot Agreement, and further complicated the post-war settlement at Versailles (see Box 2.1). 
<START BOX 2.1>

$\mathrm{CH}-02$ The Emergence of the Middle East into the Modern State System

\section{Box 2.1 Zionism and anti-Zionism, 1919}

The World Zionist Organization, bolstered by the British government's 1917 commitment to create a Jewish National Home in Palestine, submitted a memorandum to the Supreme Council at the Paris Peace Conference in February 1919. The boundaries that it claimed ran from the town of Sidon in the north (in modern Lebanon), east to the Hijaz Railway (in modern Jordan), and south to the Egyptian frontier in the Sinai. The Zionists asserted a historic claim to Palestine: 'The land is the historic home of the Jews', the memo claimed. 'By violence they were driven from Palestine, and through the ages they have never ceased to cherish the longing and hope of a return.’ They also made a humanitarian argument:

In some parts of the world, and particularly in Eastern Europe, the conditions of life of millions of Jews are deplorable ... the need of fresh outlets is urgent, both for their own sake and in the interest of the population of other races, among whom they dwell.

Finally, they argued, 'the land itself needs redemption. Much of it is left desolate. Its present condition is a standing reproach’ (Hurewitz 1979: 137-42).

These claims were rejected by the General Syrian Congress in July 1919, which submitted its resolutions to the King-Crane Commission for transmission to the Paris Peace Conference:

We oppose the pretensions of the Zionists to create a Jewish commonwealth in the southern part of Syria, known as Palestine, and oppose Zionist migration to any part of our country; for we do not acknowledge their title but consider them a grave peril to our people from the national, economical, and political points of view. Our Jewish compatriots shall enjoy our common rights and assume the common responsibilities.

(Hurewitz 1979: 180-2)

Because the King-Crane Report was never presented to the Supreme Council, there is no reason to believe that the views of the Syrian Congress were ever communicated to the peacemakers at Paris. 
$<$ END BOX 2.1 $>$

$\mathrm{CH}-02$ The Emergence of the Middle East into the Modern State System

Upon the fall of Damascus and the subsequent Ottoman retreat from the Arab lands in September 1918, Britain found itself in sole possession of the Arab Middle East. Now faced with a post-Ottoman reality, Britain had to square conflicting interests with wartime pledges to its Entente allies. This difficult task was left to the negotiations at Versailles.

\section{The post-war settlement, 1919-22}

Two features of the post-war settlement are apparent: the weak bargaining position of the Arab delegates to Versailles; and the duplicity of the great powers. For Britain and France, the colonies and territories of the vanquished German, Austrian, and Ottoman empires were seen as spoils of war (Ulrichsen 2014: 173-201; Rogan 2015: 385-406). The United States, somewhat naively, espoused a much more liberal view of a new world order, set out by President Woodrow Wilson in his well-known 'Fourteen Points' address to a joint session of Congress on 8 January 1918. Wilson spoke to the aspirations of Arab political elites in his twelfth point:

The Turkish portion of the present Ottoman Empire should be assured a secure sovereignty, but the other nationalities which are now under Turkish rule should be assured an undoubted security of life and an absolutely unmolested opportunity of autonomous development.

The Arab delegates to Versailles were early proponents of President Wilson's vision. However, they would prove no more successful than President Wilson himself in imposing a new order on old world diplomacy, a complex science of which they had little understanding and less experience.

\section{The Arabs in Versailles}

A number of delegations from former Ottoman domains sought the opportunity to press their claims before the victorious Entente powers for recognition. The Greeks pressed for territory in Anatolia. Armenians presented their case for statehood. The Hashemites, in de facto control of geographic Syria (roughly corresponding to modern Syria, Lebanon, and Jordan) and the Hijaz, sought to secure the Arab kingdom promised them 
$\mathrm{CH}-02$ The Emergence of the Middle East into the Modern State System by the Hussein-McMahon correspondence. The Zionist movement was active to uphold the Balfour promise of a Jewish national home in Palestine. And in Egypt, the British refusal to permit a delegation to go to Paris to present Egyptian claims for independence prompted a nationwide uprising in 1919 that led to a reversal of policy and the dispatch of an Egyptian delegation to Paris. In some regards, the Paris Peace Conference marked the entry of the Middle East as a region into the prevailing system of international relations. The experiences of the Arab delegations revealed the disadvantages of having their relations with the European state system mediated through Istanbul for the length of Ottoman rule.

\section{Egypt and the wafd}

The nationalist movement in Egypt had been gaining momentum in the early years of the 20th century. Under British occupation since 1882, Egypt had already developed the institutions of independent statehood. The monarchy could trace its origins back a century to the appointment of Mehmet Ali Pasha as governor of the Ottoman province of Egypt in 1805. The Pasha was to rule Egypt for forty-three years and set the province on a path to autonomy. His descendants had ruled the country ever since. The 'khedives', as the rulers of Egypt came to be designated, governed in consultation with a cabinet of ministers whose portfolios conformed to formal government divisions (for example, foreign affairs, finance, education, health). There was even a protoparliament, known as the 'Chamber of Delegates’, which met regularly between November 1866 and March 1882 (Schölch 1981). Occupation came as a result of financial and political crises, starting with the Egyptian bankruptcy in 1876 and ending with a military-led revolt against European control and Khedive Tawfiq, believed by many in Egypt to be himself under excessive European control (Owen 1981).

By the end of the 19th century, nationalist parties were formed and their views aired in a range of newspapers. Their main agenda was to end the British occupation. Such nationalist activity was contained during the long years of the First World War. Egypt was formally separated from the Ottoman Empire in November 1914, following the Ottoman entry into the war on Germany’s side, and declared a British protectorate. The Khedive was now designated a Sultan, raising expectations of independence in the aftermath of war. When 
$\mathrm{CH}-02$ The Emergence of the Middle East into the Modern State System the victorious Entente powers began to plan for a peace conference in 1918, Egyptian nationalists again mobilized. There is some dispute over who first proposed to send a delegation (in Arabic, wafd) to represent Egypt's claims, although the men who called on British High Commissioner Sir Reginald Wingate were associated with the Ummah Party. Headed by Sa'd Zaghlul, a former judge and minister of education, the delegation was rebuffed. The Egyptian public responded with petitions and growing anger. When the British authorities arrested and exiled Zaghlul and his supporters to Malta, a mass uprising followed. The 'Revolution of 1919’ rendered Egypt ungovernable, and the British were forced to recall Zaghlul from exile and arrange for him to address the delegates at the Versailles Peace Conference.

Egyptian nationalists were to return from Versailles empty-handed. On the day on which Zaghlul and his party arrived in Paris, the American delegation issued a statement recognizing Britain’s protectorate over Egypt. Egyptian hopes pinned on Woodrow Wilson’s support, raised by his Fourteen Points, were dashed. Zaghlul and his colleagues, no strangers to European politics, had learned that colonized people could change imperial politics only through domestic disorder. The Egyptian delegation returned to alternate periods of political disorder and negotiations with the British, leading up to the 1922 Treaty that ended the protectorate while preserving British influence over Egypt.

\section{The Hashemite Arab kingdom}

Following the Ottoman retreat from Damascus in 1918, Amir Faisal (crowned King of Syria in March, 1920) found himself de facto ruler of Syria, which, at that time, had no recognized boundaries or formal government. Faisal sought to consolidate his position in Syria at the Versailles Peace Conference. The greatest threat to his position came from Britain's other wartime promises. Faisal came to terms with the Balfour Declaration and signed an agreement with Zionist leader Chaim Weizmann in January 1919, conceding Palestine to the Zionist movement on condition that his demands for an Arab kingdom be otherwise accepted by the powers (Laqueur and Rubin 1985: 19-20). Faisal first learned of the Sykes-Picot Agreement when the Bolsheviks published the secret treaties of the Tsarist government in 1918, at the height of the Arab Revolt. While Faisal saw no 
$\mathrm{CH}-02$ The Emergence of the Middle East into the Modern State System alternative to continuing with the Revolt, the threat of French rule hung over his new state and he held few cards to improve his position at Versailles.

Faisal presented the Supreme Council of the Paris Peace Conference with a memorandum setting out Arab aspirations in January 1919. Faisal appeared before the Supreme Council, accompanied by T. E. Lawrence, the following month (6 February). In his memo, Faisal wrote that 'the aim of the Arab nationalist movements ... is to unite the Arabs eventually into one nation'. He based his claim on Arab ethnic and linguistic unity, on the alleged aspirations of pre-war Arab nationalist parties in Syria and Mesopotamia, and on Arab service to the Allies' war effort. He acknowledged that the various Arab lands were 'very different economically and socially', and that it would be impossible to integrate them into a single state immediately. He sought immediate and full independence for Greater Syria (including Lebanon, Syria, and Transjordan) and the western Arabian province of Hijaz; he accepted foreign intervention in Palestine to mediate between Jewish and Arab demands, and in Mesopotamia, where Britain had declared its interest in oil fields; and he declared the Yemen and the central Arabian province of Najd outside the scope of the Arab kingdom. Yet he maintained a commitment to 'an eventual union of these areas under one sovereign government'. He concluded:

In our opinion, if our independence be conceded and our local competence established, the natural influences of race, language, and interest will soon draw us into one people ... To achieve this [the great powers] must lay aside the thought of individual profits, and of their old jealousies. In a word, we ask you not to force your whole civilization upon us, but to help us to pick out what serves us from your experience. In return we can offer you little but gratitude.

(Hurewitz 1979: 130-2)

As subsequent events would prove, it was not realistic to expect Britain and France to act in so disinterested a fashion.

A second set of claims was made in the name of the Syrian people by the chairman of the Central Syrian Committee, Shukri Ghanim. Ghanim’s recommendations were diametrically opposed to those of Amir Faisal. Stressing Syria’s lack of preparation for self-rule and need for foreign assistance, Ghanim asked the Council 
$\mathrm{CH}-02$ The Emergence of the Middle East into the Modern State System of Ten to place Syria under the tutelage of France for reasons of alleged historic attachment, demonstrating a capacity to reconcile Muslims and Christians and, perhaps most improbably, its lack of imperialist interest in the region. It would later be revealed that Shukri Ghanim was a French citizen who had been away from Syria for thirty-five years (Helmreich 1974: 54-5). Indeed, France sought by all means to undermine Hashemite claims to Syria and to keep to the spirit of the Sykes-Picot disposition of Arab territory.

Faced with divergent claims on behalf of the Syrian people, with disagreement between Britain and France over the future of the Arab lands and American disapproval of the secret wartime agreements as a whole, the United States proposed to dispatch a commission of inquiry to establish the wishes of the Syrian people, and gained British and French agreement to do so. Faisal was delighted, writing to President Wilson in March 1919 to express his gratitude for granting the Arabs the opportunity to express 'their own purposes and ideals for their national future’ (Howard 1963: 35).

\section{The King-Crane Commission}

President Wilson named Oberlin College President Henry Churchill King and Chicago businessman Charles

R. Crane as commissioners. Wilson 'felt these two men were particularly qualified to go to Syria because they knew nothing about it' (Howard 1963: 37). Knowledge here was conflated with interest and Wilson sought men of integrity with no prior interests in the region. In fact, both men had extensive knowledge of the Middle East, King as a scholar of biblical history and Crane through his travels in Ottoman lands, dating back to 1878. When the British and French withdrew from the Commission, the Americans set out for Syria in May 1919 with instructions to meet local representatives and to report back on the aspirations of the Arab peoples in Syria, Iraq, and Palestine. The Commission arrived in Jaffa on 10 June, and spent six weeks touring Syria and Palestine. It held meetings in more than forty towns and rural centres, and collected more than 1,800 petitions. As James Gelvin (1998: 35) has argued, 'while the entente powers had charged the commission with a simple fact-finding mission, its presence in Syria catalysed a mobilization of the Syrian population that was unprecedented in scope'. The local Arab government distributed sermons to be read in Friday prayers in Syrian mosques, political and cultural associations were enlisted to prepare petitions for the Commission, and the 

sion.

In August 1919, the Commission withdrew to Istanbul, where King and Crane drafted their report, which was delivered to the American delegation in Paris at the end of the month. The report went no further. There is no evidence that it was ever consulted by the British or French, and it was made public only in 1922, well after the post-war settlements had been signed. Yet the King-Crane Report serves as a yardstick against which to measure the gulf that separated Arab claims of self-determination made to the commissioners from the mandate system that they received.

King and Crane summarized their findings after five weeks of collecting testimony. While noting explicit Syrian preference for full independence, they recommended a fixed-term mandate under American or, as second choice, British authority (but explicitly ruling out French administration), leading to full independence. Syria, including Palestine, should be established as a single monarchy under Faisal's rule, with Lebanon given extensive autonomy within the Syrian state. King and Crane called for major restrictions in Zionist settlement in Palestine, noting that 'more than 72 per cent-1,350 in all—of all the petitions in the whole of Syria were directed against the Zionist program’ (Hurewitz 1979: 196). In Iraq, they called for another unified monarchy under British mandate. In essence, the recommendations of the King-Crane Commission overturned the Balfour Declaration and Sykes-Picot Agreement. It is no wonder that the British and French chose to ignore the document and proceed with a modified partition plan.

\section{San Remo and the mandate system}

By the time that Britain and France reached the peace conference, the Sykes-Picot Agreement had been overtaken by events. Most importantly, the Bolshevik Revolution had led to the withdrawal of Russia's claims on Ottoman territory. The Soviets, preoccupied with securing their state against outside menace and internal challenge, would not play a major role in Arab affairs through the inter-war period.

The British position had changed in many ways since 1916 as well. For one, its armies had occupied Syria and Iraq, which gave it a better sense of its strategic imperatives and an improved bargaining position to assure 
$\mathrm{CH}-02$ The Emergence of the Middle East into the Modern State System them. Two areas in particular were to come under revision: the northern Iraqi region of Mosul, allotted to the French sphere of influence; and Palestine, which was to come under international control. These were important points of difference and they needed formal agreement.

The premiers and foreign ministers of Britain, France, and Italy, and two delegates from Japan, met in San Remo in April 1920 to agree the partition of the Arab lands. They were not alone. As Lord Curzon complained: 'Syrians, Zionists, Armenians ... They take rooms in the same hotel as we are in and they dog our footsteps wherever we go’ (Nevakivi 1969: 242). The lobbyists did not manage to influence events, because the decisions on the Arab lands had largely been negotiated and agreed between Britain and France months beforehand. France was to obtain mandates over Lebanon and Syria, spelling the end of Faisal's Arab kingdom in Damascus. In return, France conceded its claims to northern Iraq (although Mosul would not be formally conceded to the Iraq mandate until 1925) and acknowledged Britain’s rule over Palestine, including the lands east of the River Jordan stretching to Iraq that would later be made into a separate mandate of Transjordan. The British and French established a boundaries commission to agree the frontiers between their respective territories. On 24 July 1922, when the League of Nations sanctioned the decisions taken at San Remo, the boundaries of the mandates had already been agreed between Britain and France.

Britain had, with some modification, met its commitments to both the Sykes-Picot Agreement and the Balfour Declaration; only the promises to the Hashemites had been disregarded. At the end of 1920, Britain called Faisal, the deposed King of Syria, to London to gain Hashemite acceptance of the San Remo division of the Middle East. In return, Britain would place its new mandates under the sons of Sharif Hussein. This plan came to be known as the 'Sharifian solution', both a way in which partially to redeem Britain’s promises to its wartime allies and 'an interlocking political grid whereby pressure on one state could win obedience in another' (Wilson 1987: 49; Paris 2003). The Sharifian solution was made policy by Colonial Secretary Winston Churchill in the Cairo Conference in March 1921. 


\section{Churchill and the Hashemites}

$\mathrm{CH}-02$ The Emergence of the Middle East into the Modern State System

The two territories conceded to Britain at San Remo were Iraq and Palestine. Given that these were mandates rather than traditional colonies, Britain needed to devise governments for the new states. Iraq was the first item on the agenda at the Cairo Conference and it was quickly agreed that Faisal would be placed on the throne in Baghdad. A mechanism was yet to be found to gain Iraqi public acceptance of Britain's choice, although this was left to Britain's colonial agents on the ground. A referendum was held and Faisal was confirmed as King of Iraq in August 1921.

The next item on the agenda was Palestine- or rather those lands to the east of the River Jordan stretching to the Iraqi frontier that had been claimed by Britain as part of Palestine. Faisal’s brother, the Hashemite Amir Abdullah, had ridden with a group of supporters from the Hijaz to the Transjordanian town of Ma'an in a bid to reclaim Damascus from the French. While no one had any illusions that Amir Abdullah might succeed in this aim, they saw his presence in Amman as threatening to destabilize the new borders between the French and British mandates. Churchill and a delegation from the Cairo Conference proceeded to Jerusalem and met Abdullah. They struck an agreement with Amir Abdullah, who agreed to serve as provisional ruler over Transjordan for a six-month probationary period. He was given a stipend of $£ 5,000$ and assigned to contain both anti-French and anti-Zionist activity. Churchill held out the prospect of a throne in Damascus if Abdullah proved his merits to the French-a prospect that must have looked as improbable at the time as it does in hindsight. Yet with Iraq, Transjordan, and the Hijaz under Hashemite rulers, Churchill could claim to have gone as far as he could to redeem Britain's pledges to Sharif Hussein and his sons (Paris 2003). (Sharif Hussein assumed the kingship of the 'Arab Countries’ in 1916, although he was recognized by Britain only as King of the Hijaz. He abdicated in favour of his son Ali in 1924; Ali ruled until the Saudi conquest of Hijaz in 1925.)

As for Palestine itself, Britain chose to rule the mandate directly under a High Commissioner, and to develop the structures of statehood in cooperation with the Arab and Jewish communities. Neither the cooperation nor the structures were forthcoming, because Palestine came to be the arena of two rival nationalist movements, Zionist and Palestinian. 


\section{The colonial framework}

In the four years following the Ottoman retreat from Arab lands, the map of the modern Middle East was drawn. The failure of the Arab parties to attain their national aims at Versailles revealed the weakness of their bargaining position when challenging European imperial interests. Given this somewhat compromised genesis, it is all the more remarkable just how enduring the borders of the Middle East have proven.

The Middle East that emerged from the post-war negotiations was almost exclusively an Anglo-French preserve (see Figure 2.1). Algeria was a full French colony; Morocco and Tunisia protectorates; Syria and Lebanon were held as League of Nations mandates. Egypt gained nominal independence in 1922, but continued to be under British influence through a restrictive treaty. Sudan was held as a 'condominium', ruled jointly by Britain and Egypt. Aden, or South Yemen, was a British colony; Palestine, Transjordan, and Iraq were held as mandates; Britain's interests in the Persian Gulf were upheld through treaty arrangements with the ruling families in Kuwait, Bahrain, Qatar, and the sheikhdoms known as the 'Trucial States' because of the antipiracy treaties, or 'truces', signed between them and Britain. Muscat and Oman were similarly under informal British control. Libya, an Italian colony since 1911, was an exception to this Anglo-French division of the region.

\section{<START FIGURE 2.1>}

Figure 2.1 Different types of foreign control in the Middle East during the inter-war period

Source: State, Power and Politics in the Making of the Modern Middle East, Roger Owen. Copyright 2004, Routledge. Reproduced by permission of Taylor \& Francis Books UK.

\section{<END FIGURE 2.1>}

Three states in what is now called the Middle East escaped some form of colonial rule. Turkish nationalists rallied around General Mustafa Kemal (later known as ‘Atatürk’) in opposing the draconian terms of the Paris Peace Conference, culminating in the Treaty of Sèvres (August 1920) that reduced the Ottoman Empire to a rump state combining parts of northern and western Anatolia with Istanbul as its capital. The Turkish War of 
$\mathrm{CH}-02$ The Emergence of the Middle East into the Modern State System Independence (1921-22) resulted in the Republic of Turkey, the sovereignty and independence of which were recognized in the Treaty of Lausanne (24 July 1923). In the aftermath of the First World War, Iran was occupied by both British and Soviet forces. British attempts to establish a protectorate by treaty (1919) were stoutly resisted by a proto-nationalist movement. In 1921, the commander of the Iranian Cossack Brigade, Reza Khan, led a coup that brought down the Qajar dynasty and gave rise to the Pahlavi state that would rule Iran until the Islamic Revolution in 1979. And in Arabia, the forces of Abdul Aziz Al Saud (known in the West as 'ibn Saud') succeeded in uniting the Arabian Peninsula from the Persian Gulf to the Hijaz Province on the Red Sea by 1924. Britain recognized Abdul Aziz as King of the Hejaz and Nejd in 1927, and in 1932 the kingdom was renamed 'Saudi Arabia'. These three nation states pursued their own development independent of European political domination, although, in the case of Iran, British influence remained profound.

For the rest of the Middle East, the inter-war years were a period of national self-definition within the boundaries of the new states and a battle for self-determination against the colonial powers. In this, the Middle East shares a common experience with those parts of Asia and Africa that emerged into the community of nations through European imperialism in the inter-war years. The difference in the Middle East was the enduring appeal of a supranational identity based on a range of greater Arab nations transcending the colonial boundaries. The Hashemites envisioned an Arab kingdom combining the Arabian Peninsula, Greater Syria, and Iraq; others saw Egypt as an integral part of the greater Arab state; others yet saw the whole of the Middle East and North Africa, stretching right to Morocco, as part of a common Arab Islamic nation. The enduring legitimacy enjoyed by the vision of the greater Arab nation was to prove to the detriment of interstate relations in the Arab world. Those who put their own narrow nation-state interests before those of the ideal 'Arab Nation' were deemed collaborators in a European agenda of 'divide and rule'. Yet, as was to be expected, the nationalist leaderships and the confrontations that they endured with the colonial powers gave rise to vested interests within states. 


\section{'French' North Africa and Libya}

\section{$\mathrm{CH}-02$ The Emergence of the Middle East into the Modern State System}

The French colonial possessions in North Africa experienced limited nationalist agitation in the inter-war years, gaining their independence only in the 1950s and 1960s. This had the effect of limiting the involvement of North African states in the international relations of the Middle East more generally. Algeria, the first Arab state to be occupied by a European colonial power (1830), was the last to gain independence, after a violent war spanning the period 1954-62 that claimed more than a million lives. Morocco and Tunisia were protectorates rather than formal colonies, and were ruled by France through their own monarchies. Given their own institutions of state and a much smaller French colonial settler community, both Tunisia and Morocco achieved their independence earlier, with far less confrontation. Morocco’s King Muhammad V wrote demanding independence of France in 1952. His exile gave rise to an armed resistance movement that forced a French reversal and recognition of Moroccan independence on 2 March 1956 (Pennell 2000). Tunisia initiated autonomy talks with France in 1955, achieved independence as a monarchy in 1956, and declared a republic in 1957. As for Libya, following the execution of Omar al-Mukhtar in 1932, Italian rule went unchallenged until the British occupation in 1942-43. The United Nations oversaw Libya’s independence as a monarchy in 1951 (Anderson 1986).

Morocco, Algeria, and Tunisia, and to a lesser extent Libya, were bound by similar colonial histories and the timing of their independence. This has marked North Africa as a distinct subunit of the broader Arab world known as the 'Mahgreb'. Although members of the Arab League, the Mahgreb states, along with Egypt, are active in the Organization of African Unity. These four states are also marked by a special relationship with the European Mediterranean—especially Spain, France, and Italy. While tensions between Mahgreb states have been pronounced-between Morocco and Algeria in particular-there have been numerous attempts to create a union of Mahgreb states, given their common interests and geographic proximity. Yet these very differences have set the Mahgreb apart from the rest of the Arab world, hinged to some extent by the keystone Arab state, Egypt. 


\section{Egypt and the Sudan}

$\mathrm{CH}-02$ The Emergence of the Middle East into the Modern State System

Following the nationwide disturbances of 1919, the British sought to normalize relations with Egypt in such a way as to preserve their strategic interests while giving the semblance of independence. The result was a treaty replacing the protectorate with a nominally independent monarchy bound to Britain. The 1922 Treaty recognized Egypt's independence while preserving four areas under British control: the security of imperial communications in Egypt (primarily the Suez Canal); the defence of Egypt against outside aggression (assuring Britain base rights for its military); the protection of foreign interests and minorities (as enshrined in the extraterritorial rights of the Capitulations); and the Sudan. These limits on Egyptian independence were sufficiently intrusive as to prevent Egypt's admission to the League of Nations and were an enduring source of nationalist grievance.

The inter-war years have been termed Egypt’s ‘liberal age’ (Hourani 1962; Botman 1998), an era of party politics and parliamentary elections. Britain continued to dominate Egyptian politics by playing the monarchy and the parliament against each other. The most popular party by far was the Wafd, founded by Sa'd Zaghlul. In every free election, the Wafd won by landslide majorities. By the late 1930s, the death of King Fuad and accession of his son Faruq, combined with the return of the Wafd to power under the premiership of Mustafa al-Nahhas, set in motion renewed negotiations with the British authorities. On 26 August 1936, a new AngloEgyptian treaty was signed. The twenty-year treaty was essentially a defence pact that recognized Egypt's sovereignty as an independent state and paved the way for Egyptian admission to the League, in 1937. Egypt could now establish embassies and consulates for the first time. In return, the Egyptians permitted Britain to station a maximum of 10,000 troops in the Suez Canal zone during peacetime and guaranteed Britain base rights to protect its imperial lines of communications in emergency. The treaty also preserved the status quo in the Sudan, which would remain under Anglo-Egyptian rule until 1953 and gained independence only in 1956. 


\section{The mandates}

Unlike the other colonial arrangements, Britain and France were held accountable by the League of Nations for their rule in the mandates. They were required to submit annual reports to the League secretariat outlining their progress in establishing the institutions of statehood deemed prerequisite for national independence. In theory at least, the mandates were meant to be tutorial exercises in self-rule rather than out-and-out colonial rule. The experience varied widely from country to country, although in each case the combination of colonial state formation and nationalist agitation for independence set in motion the evolution of nation states from the former provinces of the Ottoman Empire.

\section{Iraq and Transjordan}

In every regard, Iraq was deemed the role-model mandate. Through an admittedly rigged referendum, King Faisal I was installed at the head of a government composed of many Arab nationalists who had fought in the Arab Revolt in the First World War. In close alliance with Britain, the institutions of statehood were established, including a constitution, a cabinet government, and an elected parliament. Oil and agricultural resources combined to endow Iraq with a viable economy. Yet the majority of Iraqis resented the British presence deeply. A nationwide revolt broke out in 1920 similar to anti-British riots in Egypt in 1919. Popular opposition to the British presence continued through the 1920s and encouraged the British to reconsider their position in Iraq. The initial treaty of alliance of October 1922 imposed the sort of limits on Iraq's sovereignty that precluded admission to the League, as had been the case in Egypt. Persistent nationalist agitation, and domestic British opposition to paying for unproductive colonies, led to the drafting of a treaty of alliance in 1930 that allowed for the termination of the mandate. Britain supported Iraq's application to the League of Nations and, in 1932, Iraq's sovereignty was recognized with membership of the League. As in the Egyptian treaty of 1936, Britain retained base rights in Iraq, transit facilities for its military, and preferential relations in diplomatic and military spheres. These restrictions notwithstanding, Iraq's emergence into the community of independent states was the envy of the Arab world (Tripp 2000). 
$\mathrm{CH}-02$ The Emergence of the Middle East into the Modern State System

The only other Arab state to negotiate the end of its mandate was Transjordan, although its mandate outlived the League itself. The long duration of the mandate reflects the low level of opposition to what was in fact a very light British presence. Amir Abdullah secured his rule over the Transjordan and was maintained on a modest British subsidy. The main objective of Abdullah's politics was the aggrandisement of his modest state. His first target was Damascus and he enjoyed close ties with some Syrian nationalists, such as Dr Abd al-Rahman Shahbandar, as well as with Druze leaders in southern Syria. Both the French mandate authorities and the majority of Syrian nationalists opposed Abdullah’s 'Greater Syria' plans. Abdullah also looked to Palestine for access to the Mediterranean. His quick acceptance of partition plans for Palestine when first pronounced in 1937 led to widespread Arab criticism of Abdullah (Wilson 1987). Abdullah, whose introduction to international diplomacy came through representing his father Sharif Hussein in his wartime negotiations with Sir Henry McMahon, developed extensive experience of international relations through his long rule (1921-51) and close ties to Britain. He was one of the most active leaders in inter-Arab relations and had the most exchanges with the Jewish Executive in Palestine (Shlaim 1988). However, his first attempt at negotiating the end of the mandate in 1946 led to so partial an independence that the United States refused to recognize the state and blocked Transjordan's entry to the new United Nations (Dann 1984). It was not until 1948, when Britain and Transjordan signed a treaty less restrictive of its sovereignty that Transjordan gained American recognition—and not until 1955 that the country was admitted to the United Nations.

\section{Palestine}

If Iraq was the most successful British mandate and Transjordan the easiest, Palestine was to prove the most unsuccessful and difficult of British colonial possessions in the Middle East. The origins of the problem may be traced to the contradictions inherent in the Balfour Declaration. Arguably, there was no mechanism for Britain to establish a Jewish national home without disadvantage to the rights of the indigenous Palestinian Arabs. The mandate structure and the Jewish nationalist ideology of Zionism gave rise to an active Palestinian nationalist movement demanding full sovereignty over all Palestine, an end to Jewish immigration, and an end to the British mandate that provided the framework for the Jewish national home. Palestinian resistance to the 
$\mathrm{CH}-02$ The Emergence of the Middle East into the Modern State System mandate and refusal to participate in its institutions prevented the building of any enduring state structure. On the other hand, the Yishuv, as the Jewish community in Palestine was called, cooperated fully with the British and initiated a process of state-building, establishing a trade union movement, a modified cabinet government, and even its own military. With their close links to the World Zionist Organization, the Jewish Executive enjoyed a degree of experience in negotiations with European powers that the Palestinians would never match. In essence, the Palestinians could force changes in British policy only through confrontation. Riots, economic boycott, and an all-out armed revolt lasting nearly three years (1936-39) produced commissions of inquiry, a raft of White Papers, and finally in 1939 a programme of reduced Jewish immigration and the promise of independence in a decade. The terms of the 1939 White Paper were rejected by the Zionists and, between 1945 and 1947, radical Jewish groups engaged in a terror campaign against the British authorities in Palestine. Britain conceded defeat in 1947 and referred the Palestine problem to the United Nations for resolution. The UN voted for the partition of Palestine into Jewish and Arab areas, setting off a war that raged within Palestine through the spring of 1948 and, following the British withdrawal on 14 May, exploded into the first ArabIsraeli War (Segev 2000).

\section{Syria and Lebanon}

The French created very different mandates in Syria and Lebanon. In Lebanon, they merged the highlands of Mount Lebanon with the coastal plain from Tyre to Tripoli and the Biqa Valley, stretching between the Lebanon and Anti-Lebanon Mountain chains, to create the state of 'Grand Liban', or Greater Lebanon. The aim was to create the largest territorial expanse, while preserving a Christian majority. While this plan was opposed by Sunni Muslims and Druzes, the colonial power enjoyed the ardent support of their Maronite allies and the tacit agreement of other Christian communities. Greater Lebanon was established by decree of General Henri Gouraud, commander-in-chief of French forces in the Levant and High Commissioner, and declared an anomalous ‘independent State under French Mandate’ (Salibi 1977: 164). After six years under French military governors, the Lebanese Republic was founded in 1926, with an elected chamber of deputies, an appointed senate, a constitution, and a president selected by the two chambers. There were, of course, nationalists who 
$\mathrm{CH}-02$ The Emergence of the Middle East into the Modern State System opposed the great influence the French mandate authority exercised over the nominally independent Lebanon, symbolized by the original national flag, which imposed a Lebanese cedar on the French Tricolore. While the Lebanese enjoyed autonomy in domestic affairs, France assumed full responsibility for Lebanon’s foreign relations and defence. During the 1920s and 1930s, the institutions of the Lebanese state came increasingly into conflict with the mandatory power and sought fuller independence. A range of nationalist movements pulled Lebanon in different directions: some called for Lebanon to be reattached to Syria; others sought the end of the mandate and full independence.

The French enjoyed virtually no indigenous support in their Syrian mandate. They sent a military force to drive out King Faisal and his supporters, and to occupy Damascus. The French engaged a small force of irregulars at Khan Maysalun on 24 July 1920, entered Damascus the following day, and asked Faisal to leave on 27 July. This blatant disregard of Syrian self-determination for colonial ends blighted Franco-Syrian relations from the start. Subsequent French efforts to break Syria into four smaller units based around Damascus, Aleppo, and two minority statelets for the Alawites and Druzes provoked fierce opposition for the clear attempt at divide and rule. In July 1925, the Druze launched a proto-nationalist revolt against French administrative measures that spread to Damascus and the rest of Syria, and which raged for two years. Peace was restored only when the territorial integrity of Syria was respected. These events consolidated nationalist forces fragmented by the years of fighting the French into what came to be known as the 'National Bloc', which sought to attain Syrian independence through negotiations (Khoury 1987).

The end of the mandates in Syria and Lebanon followed similar trajectories. France sought to curtail nationalist dissent with treaties granting independence to both states in 1936. Modelled on the Anglo-Iraqi Treaty of 1930, the Syrian treaty was widely accepted, while the treaty in Lebanon proved very controversial, provoking clashes between its advocates and its detractors. Neither instrument was ratified by the French Chamber by the outbreak of war in 1939. The mandates looked slated for termination in 1941, with the Allied occupation and the Free French declaration of the independence of Syria and Lebanon. In practice, though, the French sought to preserve their authority. The Lebanese were the first to achieve independence. General elections were held in Lebanon in the summer of 1943. The new chamber elected Bishara Khuri president and 
$\mathrm{CH}-02$ The Emergence of the Middle East into the Modern State System purged all French prerogatives of the mandate from the constitution. French efforts to arrest Khuri and his government, and to reassert their prerogatives, provoked nationwide resistance and a reversal of policy that led to full Lebanese independence. In Syria, too, independence was initiated through constitutional reform, and by 1944 both Syria and Lebanon gained international recognition. By declaring war on Germany in 1945, both Syria and Lebanon were invited to the conference founding the United Nations. However, France retained forces in both Syria and Lebanon, and sought preferential treaties before withdrawing. It was only after Syria and Lebanon had brought UN pressure to bear that France withdrew its troops from Syria (April 1946) and Lebanon (December 1946), and both countries could claim full independence.

\section{The colonial experience: an assessment}

These brief historical overviews demonstrate that, while each Middle Eastern state had a distinct inter-war encounter with imperialism, the colonial experience left certain common legacies. The post-war settlement created a number of new states. Within their new, European-drawn boundaries, a process of state formation was initiated under strict imperial control. The new states were insulated from foreign affairs by their colonial masters. Politics were overwhelmingly domestic, and domestic politics were dominated by the search for national independence. The struggle for independence created vested interests in the individual nation states that conflicted with popular notions of a greater Arab nation. By the time independence was achieved, in nearly all cases in the aftermath of the Second World War, the newly emergent states of the Middle East were hardly better integrated to the prevailing system of international diplomacy than they had been at the end of the First World War. Relations between Arab states were fraught with rivalries and factionalism that undermined regional organizations such as the Arab League, and the Arabs were ineffectual in such international arenas as the United Nations and in great power diplomacy. These weaknesses were apparent in the Arab handling of the Palestine crisis of 1947-49.

\section{The Arab states and the Palestine crisis}

Following the Second World War, Britain found its position in Palestine increasingly untenable. Armed conflict with Jewish groups and demoralizing terror attacks placed a burden on British armed forces when the 
$\mathrm{CH}-02$ The Emergence of the Middle East into the Modern State System shattered post-war economy could least bear it. In the end, Foreign Secretary Ernest Bevin referred the Palestine question to the United Nations for resolution.

The UN resolved in November 1947 to partition Palestine into two states. The six Arab members of the United Nations (Egypt, Lebanon, Saudi Arabia, and Syria were founding members; Iraq joined in December 1945 and Yemen in 1947) all opposed partition, but had no impact on the debate within the General Assembly. They failed to build a coalition of nations to support Arab claims to Palestine and were outmanoeuvred by the Jewish Agency. The final vote in the General Assembly was thirty-three to thirteen, giving the necessary twothirds majority to ensure the passing of the Partition Resolution (Hurewitz 1976: 301).

While one might make allowances for the difficulties that the Arab states encountered in going against policies advocated by such great powers as Britain and America, they were hardly more accomplished in interArab diplomacy, as witnessed by the ineffectual actions of the Arab League. The Arab states were deeply divided and distrustful of one another. King Faruq of Egypt and King Abdul Aziz ibn Saud of Saudi Arabia sought to contain the Hashemite kings of Iraq and Transjordan. King Abdullah of Transjordan and Hajj Amin al-Husseini, the leader of the Arab Higher Committee of Palestine, loathed each other. The President of Syria, Shukri al-Quwwatly, feared King Abdullah’s ambitions in Syria (Rogan and Shlaim 2007). The Arab League engaged in a series of fruitless summits to address the growing crisis in Palestine across 1947 and 1948.

The incongruous territories allotted to the Jewish and Arab states were not acceptable to either party (although the Yishuv formally accepted the terms of the UN Resolution), and the Partition Resolution gave rise to a civil conflict in Palestine in which Jewish forces occupied several Palestinian cities in the autumn of 1947 and spring of 1948 (most notably Tiberias, Safad, Haifa, and Jaffa). Even when war was inevitable, the Arab League decided only two days before the end of the mandate in May 1948 to dispatch the armies of Egypt, Iraq, Syria, and Lebanon into Palestine, along with Transjordan’s Arab Legion. This last-minute invasion involved a fraction of the national armies involved: only 10,000 Egyptian soldiers, 3,000 Syrians, 3,000 Iraqis, and 1,000 Lebanese, in addition to the 4,500 Transjordanians-well below the forces necessary to achieve a strategic advantage over Jewish forces. King Abdullah was named commander-in-chief of the Arab forces, but each nation’s army operated under its own commanders without any overall coordination. 
$\mathrm{CH}-02$ The Emergence of the Middle East into the Modern State System

Immediately following the termination of the mandate and the withdrawal of British troops from Palestine on 14 May 1948, Israel declared its statehood. The armies of Syria, Lebanon, Iraq, Transjordan, and Egypt invaded Palestine to engage the Jewish forces. Between 15 May 1948 and the end of hostilities on 7 January 1949, the State of Israel contained or defeated all of the Arab armies and expanded its boundaries to embrace 78 per cent of the Palestine mandate. The military defeat in Palestine reflected both a failure by the newly emergent Arab states in international diplomacy and the legacies of the colonial experience. In effect, the nationalist leaders who oversaw the transition to independence within the boundaries of the colonial states fell at their first hurdle when they failed to live up to their rhetoric and save Arab Palestine from the Zionist threat (Rogan and Shlaim 2007). The Arab defeat in Palestine was to continue to plague the international relations of the region into the early 21st century.

\section{Conclusion}

The Palestine crisis brought to light Arab weaknesses in the international arena and in regional affairs that were a legacy of the way in which the colonial powers shaped the emergence of the modern Middle East. It was also a harbinger of the problems that would plague the region for decades to come.

Coming out of the Ottoman experience, the Arabs aspired to national independence. Promises of a new order of international relations, set out by US President Wilson in his Fourteen Points, generated expectations of national self-determination; instead, the Arabs found themselves denied any say in the disposition of their lands and under British or French colonial rule. Within the parameters of these new states, again shaped without the consent of those governed, Arab politics were primarily focused on gaining independence from colonial rule. The new Arab states had little or no exposure to the international order so long as their colonial masters oversaw their foreign affairs. This extended to inter-Arab affairs, often divided between those states under British and those under French rule. Thus divided, domestic interests prevailed over broader Arab interests in a way that allowed the colonial powers, and later even the young State of Israel, to play the Arab states against each other. 
$\mathrm{CH}-02$ The Emergence of the Middle East into the Modern State System

The manner in which the Middle East was shaped in the inter-war years produced a number of stable states that have, with time, established themselves in the community of nations. It also gave rise to enduring problems that have troubled the region and the international order. The most obvious example was in Palestine, where the rival national claims have made the Arab-Israeli conflict an enduring feature of the international relations of the Middle East. French efforts to create the largest possible state for their Maronite clients in Lebanon, and the sectarian system that they helped to shape to govern the many religious communities that fell within its boundaries, laid the foundations for one of the most violent civil wars in the Arab world (197591). Yet it is Iraq that has proved the most unsettling to the international system. The decision to create a state of the three Ottoman provinces of Mosul, Baghdad, and Basra laid to rest promises of a state that would have served as a homeland to the Kurdish people. Instead, the Kurds distributed between Turkey, Iran, Iraq, and Syria have known periods of intense nationalist agitation and civil war. Noteworthy examples were the Kurdistan Workers’ Party (PKK) insurgency in Eastern Turkey of the 1980s and 1990s, and the numerous Kurdish uprisings in Iraq, repressed with increasing brutality by the Baathist regime, including the use of gas against the villagers of Halabja. Yet it was Iraq's claims to territories formerly associated with the Ottoman province of Basra in the modern state of Kuwait $(1937,1961$, and 1990) that have provoked the greatest wars to rock the region (see Box 2.2). Saddam Hussein's invasion of Kuwait on 2 August 1990 divided the Arab world and led to war in 1991, twelve years of sanctions, and a second war in 2003. The emergence of the state system in the Middle East is thus a history both of the creation of stable states and of destabilizing conflicts.

\section{<START BOX 2.2>}

\section{Box 2.2 Iraqi claims to Kuwait}

In the late 19th century, the Ottoman Empire sought to extend its sovereignty over a number of Arab territories in the Persian Gulf, including Kuwait, Qatar, and the Hasa region, now the Eastern Province of Saudi Arabia. It conferred titles on local rulers and claimed their territories as integral parts of Ottoman provinces. Members of the ruling Sabah family of Kuwait were recognized as district governors and their territories nominally attached to the Ottoman province of Basra. Britain, which had long sought to preserve 
$\mathrm{CH}-02$ The Emergence of the Middle East into the Modern State System the Persian Gulf under its exclusive influence, sought to counter Ottoman efforts at every turn. In 1899, the British government concluded an exclusive agreement with the ruling sheikh of Kuwait, Mubarak al-Sabah (1896-1915), by which:

the said Sheikh Mubarak-bin-Sheikh Subah [sic] of his own free will and desire does hereby pledge and bind himself, his heirs and successors not to receive the Agent or Representative of any Power or Government at Koweit [sic], or at any other place within the limits of his territory, without the previous sanction of the British Government.

(Hurewitz 1975: 475-7)

The Ottomans were never reconciled to Britain's protectorate over Kuwait. With the creation of the modern state of Iraq after the break-up of the Ottoman Empire, the independence of Kuwait was to be challenged on three separate occasions.

- In 1937, Iraqi King Ghazi asserted Iraq's sovereignty over Kuwait as part of a general criticism of Britain's position in Iraq and the Gulf. Two years later, Ghazi died in a car crash and nothing came of his claims.

- The issue was revived in 1961, when Kuwait was given its independence by Britain. Iraqi President Abd al-Karim Qasim tried to revert to Ottoman practice, declaring the sheikh of Kuwait a district governor subordinate to the governor of the Iraqi Province of Basra. Britain responded by dispatching troops to Kuwait and referred the matter to the United Nations, before Iraq withdrew its claim.

- Saddam Hussein's invasion of Kuwait in the summer of 1990 was thus the third and most forceful Iraqi claim to its oil-rich Gulf neighbour, justified, as in the past, on anti-imperial and pan-Arab grounds, undoing the divisions imposed on the Arab world by the British Empire. 
$<$ END BOX 2.2>

\section{Key events}

1839 Gülhane Reform Decree initiates the period of Ottoman reforms known as the Tanzimat

1856 Reform Decree confers equality on non-Muslims, the most controversial reform of the Tanzimat

1876 Promulgation of the Ottoman Constitution

1882 British occupation of Egypt

1914 Ottoman Empire enters the First World War in alliance with Germany

1917 British government declares official support for Zionism (Balfour Declaration)

1918 Surrender of Ottoman forces and occupation of Ottoman territory by Entente powers

1919 Paris Peace Conference

1920 Anglo-French partition of former Arab territories of the Ottoman Empire agreed at San Remo

1922 Partial independence for Egypt and election of Wafd government headed by Sa'd Zaghlul

1929 Anti-Zionist riots in Palestine

1932 Anglo-Iraq treaty terminates the mandate in Iraq, which is admitted to the League of Nations

1936 Anglo-Egyptian treaty confers nominal independence on Egypt, which is admitted to the League of Nations

Independence treaty concluded between France and its two Levantine mandates, Syria and Lebanon; French parliament fails to ratify the treaties

1936-39 Arab Revolt in Palestine

1941 Free French declaration of Syrian and Lebanese independence

1946 Full independence in Syria and Lebanon, with the withdrawal of all French troops

1947 United Nations passes Resolution to partition Palestine to create Arab and Jewish states

1948 End of the British mandate in Palestine, declaration of Israeli statehood, and the first Arab-Israeli War

1949 Colonel Husni al-Za’im overthrows Syrian government in a military coup 
$\mathrm{CH}-02$ The Emergence of the Middle East into the Modern State System Assassination of King Abdullah of Jordan

1952 Free Officers’ Revolution overthrows the Egyptian monarchy and brings Gamal Abd al-Nasser to power

\section{Further reading}

Brown, L. C. (1984) International Politics and the Middle East: Old Rules, Dangerous Game (Princeton, NJ: Princeton University Press)

An excellent study that traces the evolution of the 19th-century 'Eastern Question' into the troubled Arab state system of the 20th century.

Fromkin, D. (2000) A Peace to End All Peace: Creating the Modern Middle East, 1914-1922 (Harmondsworth: Penguin)

This book discusses the formative period of the First World War and the Versailles Treaty in shaping the Arab state system.

Hourani, A. (2002) A History of the Arab Peoples (London: Faber \& Faber)

A magisterial study, among the best general histories of the Middle East in the 20th century. See especially Parts IV and V.

Hurewitz, J. C. (1975) The Middle East and North Africa in World Politics: A Documentary Record, vol. 1, European Expansion, 1535-1914; (1979) The Middle East and North Africa in World Politics: A Documentary Record, vol. 2, British-French Supremacy,1914-1945 (2nd edn, New Haven, CT: Yale University Press)

A two-volume compilation that comprises the best collection of documents on the diplomacy of the Middle East.

Rogan, E. (2009) The Arabs: A History (Harmondsworth: Penguin)

An interpretation of the history of the Middle East and North Africa, from the Ottoman conquests to the present day, which expands upon the treatment of the modern period in Hourani (2002). 
$\mathrm{CH}-02$ The Emergence of the Middle East into the Modern State System Rogan, E., and Shlaim, A. (eds) (2007) The War for Palestine: Rewriting the History of 1948 (2nd edn, Cambridge: Cambridge University Press).

An edited volume that traces the inter-Arab divisions underlying Israeli victory in the first Arab-Israeli War.

Yapp, M. E. (1987) The Making of the Modern Near East, 1792-1923; (1991) The Near East since the First World War (London and New York: Longman)

A highly recommended two-volume history. 